\title{
El professor Besalú i la renovació pedagògica: en defensa de la tradició i de l'actitud il.lustrada
}

\author{
Conrad Vilanou (Universitat de Barcelona)
}

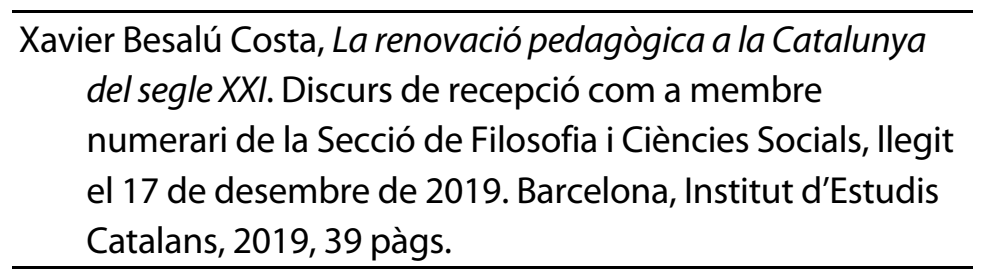

Ens congratula presentar el discurs d'ingrés com a membre de l'Institut d'Estudis Catalans del professor Xavier Besalú, mestre i pedagog, que ha impartit durant molts anys docència a la Universitat de Girona i que ha ocupat llocs de responsabilitat en diferents organismes i institucions, entre les que destaca Rosa Sensat, sense oblidar la seva militància sindical i en organitzacions com Càritas. De fet, abans d'aquest reconeixement, aquesta revista el va convidar a deixar constància del seu testimoni pedagògic, de la seva trajectòria personal, cosa que va fer amb l'article «Una formació: escenaris, persones, lectures» (TE, núm. 44, 2013, p. 211-238). A banda de la seva història vital, en què va donar compte i raó del seu compromís amb els més vulnerables, quelcom que ha estat una constant en una vida dirigida a lluitar contra la pobresa i les injustícies socials, el professor Besalú ha publicat altres treballs com ara són «Perplexitat, miratges i resistències (el retorn de la pedagogia)» (TE, núm. 26, 2002, p. 213-235), «L'escola i el futur» (TE, 28, 2015, p. 257-274), «Pedagogia, instituts d'educació secundària i orientació educativa» (TE, núm. 43, 2012, p. 281-292) i «Infants i joves gitanos: èxit escolar i construcció de la identitat» (TE, 48, 2015, p. 257-274). Ens trobem, doncs, davant d'un autor compromès socialment $i$ cívica, que coneix els problemes de prop i que ens ha confiat diversos originals que traspuen una convicció ferma en el valor de l'educació com a vehicle de transformació social i, alhora, una participació inequívoca amb el pensament crític i la renovació pedagògica, d'acord amb una tradició històrica que ve de lluny. Podem afegir que el professor Besalú roman allunyat de pensades i ocurrències genialoides, alhora que es desmarca quan convé d'allò políticament correcte. A la vista del que diem, no és gens estrany que l'Institut d'Estudis Catalans hagi reconegut la vàlua i els mèrits del professor Besalú que així assoleix la distinció de ser membre de l'Acadèmia científica de Catalunya per excel-lència.

D'acord amb el seu perfil intel-lectual, la lectura d'aquest discurs no ens ha decebut, com era d'esperar en un intel.lectual de pedra picada, que no combrega amb rodes de molí i que diu les coses pel seu nom. Ja vam tenir aquesta impressió el dia en què va pronunciar-lo a la Sala Prat de la Riba de la docta institució del carrer del Carme, instal.lada en l'antiga Casa de Convalescència de I'hospital de Sant Pau. A grans trets, podem avançar dues idees força que es desprenen d'aquest parlament com som el reconeixement de l'existència d'una llarga tradició en la renovació pedagògica, amb dos moments estel.lars 
com són les quatre primeres dècades del segle XX i els anys cinquanta-seixanta, amb la data rellevant del 1965, moment de la posada en marxa del moviment de mestres de Rosa Sensat, i, per altra banda, una concepció moderna de la pedagogia, al marge de qualsevol futilitat postmoderna. Potser pagui la pena aclarir el professor Besalú no entén l'educació com un projecte il.lustrat sinó que ho fa amb una actitud il.lustrada, que no és ben bé el mateix, posició amb la que clou contundentment el seu discurs, com no podia ser d'una altra manera. A propòsit d'això, ho podem reblar amb les paraules següents que talment posen de relleu el seu credo pedagògic: «la confiança en la raó, la defensa aferrissada de la llibertat i la convicció que malgrat tot hi ha uns valors universals, que les persones som capaces de pensar i de decidir sense tuteles, de fer-nos responsables de les nostres accions i decisions; contra la indiferència que s'assenta damunt la interessada mercantilització de la societat, educació inclosa» (p. 32).

Imbuït per aquesta filosofia, que forneix una autèntica declaració de principis que apareix com a colofó del discurs, el professor Besalú aborda el panorama general de la renovació pedagògica. Si sovint diem que pensar és dibuixar, el que ha fet el professor Besalú amb aquest text és perfilar un mapa conceptual i discursiu, amb la intenció de destriar el gra de la palla, és a dir, d'escatir aquelles accions innovadores que responen a criteris publicitaris de màrqueting $i$ aquelles altres instàncies que, amb més silenci i sense una projecció social escampada a bombo i platerets com a voltes succeeix, constitueixen veritables assaigs de renovació pedagògica. Tampoc es pot perdre de vista que el professor Besalú pensa genèticament de manera que al seu parer la renovació pedagògica afaiçona un procés de llarga duració, de més de cent anys, i en el que es detecten iniciatives que van gaudir de l'aixopluc públic a través dels vents noucentistes, al costat d'altres que van sorgir entre els mestres públics de petits pobles, sense comptar els que procedien de les escoles racionalistes $\mathrm{i}$ ateneus obrers que s'endinsen el segle XIX. Altrament, després d'aquest període inicial que va arribar fins 1939, estroncat per la dictadura franquista, van sorgir escoles amb voluntat renovadora tot i les circumstàncies adverses del moment, i així es va traçar un itinerari que a través de les Escoles d'Estiu, organitzades per Rosa Sensat, va arribar fins al moviment de la CEPEPC (1983) que va permetre que moltes d'elles passessin a la xarxa pública l'any 1988. Dit amb altres paraules: la renovació pedagògica té història, i no es pot considerar -com alguns fan per desconeixement- que sigui quelcom que sorgeixi de nova planta, gràcies a les idees d'alguns il.luminats que s'han enlluernat en els darrers anys amb aspectes com ara el progrés tecnològic, vist como una nova panacea messiànica i salvífica de l'educació, o els sistemes d'altres països com Finlàndia, tan allunyats a la nostra realitat històrica i cultural i, fins i tot, religiosa.

Per tant, el professor Besalú -que sap de què parla- posa ordre en el garbuix de les escoles i projectes innovadors que es donen entre nosaltres, i que sovint recuperen velles pedagogies ja conegudes (Montessori, pedagogia Waldorf, els mètodes de projectes, etc.), amb una fina cirurgia que deixa les coses en el seu lloc. Llegir el professor Besalú sempre és un goig que activa l'enginy perquè a més de dir les coses pel seu nom, tal com són sense retòriques ni barroquismes, esperona la intel.ligència del lector que es sotmès a un impacte continuat de frases punyents i aclariments precisos que permeten discernir entre les anècdotes i les categories. I en aquest sentit, i pel que fa a la renovació pe- 
dagògica, cal destacar determinats projectes com la Xarxa d'Educació Lliure (XELL), Escola Nova 21 i Horitzó 2020 que han aparegut en els darrers anys, com si fossin una espècie de bolets, sorgits quasi bé per generació espontània sovint al marge de la tradició històrica que el professor Besalú reconeix que atresora un pes que, per alguns moguts per les modes i la voluntat d'impressionar (épater), han menystingut o arraconat simplement. En aquest punt, potser sigui oportú recordar aquelles paraules de Raimon quan deia que qui perd els seus orígens, perd la seva identitat, o bé aquelles altres d'Eugeni d'Ors en què manifestava que fora de la tradició tot era plagi, com a voltes esdevé en alguns projectes innovadors més preocupats pel que passa lluny de casa (els Estats Units com a meca i model de la civilització occidental) que no pas pendents de la nostra pròpia tradició i trajectòria que -vulguem o noes troba incardinada en la vella Europa que també ha esdevingut en el transcurs del temps una via pedagògica. No debades, el professor Alexandre Sanvisens va perfilar el sentit de la nostra trajectòria pedagògica en un text que es va incloure en la Guia didàctica per a l'investigador de la història de la pedagogia catalana (1978) i que, més tard, es va recuperar en el llibre Doctor Alexandre Sanvisens Marfull, pedagog ipensador (2005).

En una línia que recorda el posicionament del Dr. Sanvisens, el professor Besalú reflexiona sobre el que significa innovar en educació que no es pot circumscriure a una operació de mediacions didàctiques o únicament d'eines tecnològiques, sinó quelcom més profund perquè implica «canviar la gramàtica escolar, aquesta mena d'imaginari col-lectiu sobre què és una escola» (p. 13). Sumem-hi el que afegeix a continuació en el sentit que «una innovació educativa no és una reforma de l'ensenyament», ni tampoc és «sinònim de modernització o de posada al dia, sobretot de tecnologia, d'aparellatge, d'equipament, d'imatge o de continguts: la modernització és necessària, però no és garantia d'innovació si no afecta la gramàtica o els elements substantius» (p. 13-14). Comptat i debatut, la pedagogia no és només una qüestió de tècniques (tekné), si no que reclama un fonament (Grund) que ens remet a reflexions filosòfiques, teorètiques $i$, fins i tot, teològiques. Tinguem en compte, a més, que la pedagogia d'arrel cristiana va tenir un paper cabdal en la renovació pedagògica des de mitjans del segle passat, amb referents com Roser Pujades i Pau López Castellote, que l'any 1976 va promoure el Consell Català d'Ensenyament (1976), una alternativa confesional al document «Per una nova Escola Pública Catalana», declaració de l'onzena Escola d'Estiu (Barcelona, 1976), noms que lamentablement no veiem en el text en qüestió, per bé que el professor Besalú reconeix l'aportació de la Fundació Escola Cristiana de Catalunya en el camp de la renovació pedagògica (p. 22).

Si se'ns permet emprar una terminologia escolàstica, podem dir que la innovació no pot romandre en quelcom accidental, sinó que ha de ser radical, ha d'anar a la rel, és a dir, al contingut material, a la substància, per la qual cosa s'ha de defugir de les modes que emfasitzen el «fonamentalisme tan occidental que creu en la inevitabilitat del progrés i de la tecnologia per a la millora de l'educació, en la necessitat del canvi continu per avançar» (p. 14). D'acord amb aquest plantejament, que al cap i a la fi reclama la necessitat d'una teoria de l'educació integral i ben fonamentada, els trets que caracteritzen qualsevol innovació educativa exigeixen tres requisits que corresponen a tres tradicions, a saber, «la de l'excel-lència (que posa al centre la ciència i la tecnologia), la cultural (que posa al centre la vida) i la crítica (que posa 
al centre l'emancipació)»(p. 14). Per consegüent, innovar a l'era digital no es pot limitar al primer d'aquests tres aspectes, com en ocasions esdevé, sinó que ha d'aprofundir en totes aquestes direccions, fins al punt que Besalú -tot estrafent $X$. Martínez-Celorrio- es fa ressò del que alguns analistes qualifiquen de canvi educatiu genuí, «per diferenciar-lo dels canvis centrats en les tecnologies digitals, dels programes d'innovació propiciats des de I'Administració educativa o dels canvis dissenyats per consultores privades» (p. 17). Des d'aquesta perspectiva, el perill que es centra en la innovació eductiva rau en dos aspectes, com són la banalització de la innovació, convertida en una simple moda sense res més que pura aparença, talment com si es tractés d'una operació de maquillatge, i la mercantilització que es deriva d'aquesta actitud innovadora que té molt de màrqueting per fer vendre determinats productes pedagògics que són presentats com la solució màgica per resoldre tots els problemes que afecten al món educatiu, enmig d'una societat neoliberal i altament competitiva en què moltes famílies veuen en l'educació una inversió a llarg termini, per tal que llurs fills reïxin enmig de la lluita per l'èxit professional en una societat que ha precarietzat el món laboral.

No es pas debades dir que un dels trets d'aquest breu text rau en la seva dimensió sistemàtica i en aquesta direcció Besalú es fa ressò del plantejament del professor Jaume Carbonell que va procedir a una taxonomia de l'educació i de les pedagogies progressistes que va classificar de la següent manera: pedagogies crítiques; pedagogies lliures no directives; pedagogies de la inclusió i la cooperació; la pedagogia lenta, serena i sostenible; la pedagogia sistèmica; les pedagogies del coneixement integral i pedagogies de les intel.ligències múltiples. Per altra part, el professor Besalú duu a terme un balanç provisional en deu notes de la renovació pedagògica que constitueix una mena de síntesi ordenada del seu pensament al respecte, on recull aspectes desenvolupats anteriorment, $i$ introdueix nous elements de consideració. Entre altres punts, per les limitacions de l'espai no podem comentar els deu aspectes, destaca que la Llei d'educació de Catalunya de 2009 ha estat «un factor important d'aquesta efervescència innovadora» mentre que la Llei orgànica per a la millora de la qualitat educativa (LOMCE), de 2012, ha estat un fre, atès que suposa «una càrrega profunda de recentralització, d'anticatalanisme, de confessionalitat i de mala pedagogia, que ha obligat tothom a centrar els esforços a salvar l'essencial del model català» (p. 23).

Ens hem d'apressar a dir que un altre dels nuclis forts d'aquest discurs -i que ja hem esmentat més amunt- rau en la proposta de procedir a «canvis substantius en la gramàtica escolar tradicional amb voluntat de de perpetuar-se» (p. 23). També cal fer notar que aquesta nova gramàtica ha de ser el resultat d'una actitud de compromís amb un pensament crític, que uneix tradició i innovació, que assumeix el gir no només tecnològic sinó també social que va assumir l'educació a partir de la dècada dels anys seixanta del segle passat. Llavors van emergir una sèrie de novetats, derivades de la defensa dels drets civils de les minories en un context descolonitzador, que van desencadenar moviments $i$ discursos en defensa de les diferències (feminisme, antiracisme, pacifisme, ecologisme, etc.) després que la identitat d'un únic món occidental, mercantilista, militarista, etnocèntric i colonial, que marcava I'hegemonia del nord sobre el sud, entrés en crisi.

A la vista del que hem exposat, podem ressaltar que aquí rau un punt de diferència respecte a la majoria de propostes d'innovació que no participen d'aquest doble 
compromís de veure en l'educació un instrument de canvi progressista i de correcció de les desigualtats socials. En comptes d'això, i sota l'aparença d'un llenguatge d'alta tecnologia amb una bateria de conceptes que procedeixen del món anglosaxó, «la major part de les innovacions acaben sent socialment conservadores, explícitament despolititzades i força coherents amb els valors hegemònics en el món històric en què es produeixen» (p. 24). Com es pot comprovar, el professor Besalú opta pel camí del treball honest, humil i quotidià, sense els escarafalls de les grans declaracions i manifestacions publicitàries, tal com ha succeït amb l'esclat del programa «Escola Nova 21» que ha gaudit d'un suport mediàtic sense precedents i que ha deixat a les fosques l'esforç de molts mestres que des de fa dècades treballen d'una manera abnegada i compromesa i, nogensmenys, exemplar. Quelcom similar ha succeït amb la XELL que, a partir de la classificació del professor Xavier Laudo, Besalú considera que forma part de les pedagogies líquides, mentre que «Escola Nova 21» i «Horitzó 2020» entrarien en l'àmbit de les pedagogies gelificades o paradoxals, la qual cosa vol dir que són pedagogies que no comparteixen valors sòlids, sinó que a tot estirar assumeixen un estat intermedi «entre el sòlid i el líquid, entre l'opacitat i la transparència» (p. 29). Ras i curt: d'aquests tres aquests programes d'innovació, amb gran ressò mediàtic, no hi ha cap que entri dins de l'esfera d'allò sòlid que aposta per radicalitzar els valors fundacionals de l'escola pública, o, el que és el mateix, «l'emancipació dels individus, el pensament crític, la responsabilitat i la voluntat de defensar-se del mal, i la capacitat de viure amb els altres i de treballar pel bé comú» (p. 28).

És clar que Xavier Besalú, sempre crític i amb un punt de sornegueria com a bon empordanès, es desmarca de la «retòrica de la innovació» i es manté dins d'una trajectòria que ve de lluny, «que no renega de la tradició, sinó que l'estudia, la recrea i la vivifica» (p. 31) i no accepta fàcilment totes aquelles propostes que volen ser pregonament trencadores i significativament transformadores fins al punt que volen capgirar l'orde de les coses, però que no fan més que oferir «fugides cap endavant» (p. 31). Arriba el moment de cloure aquest comentari, tot dient que possiblement poques vegades un discurs hagi donat tan de joc per analitzar un del tòpics que sovint s'escolta en relació al món de l'educació, on últimament han anat a raure tot un seguit de periodistes, tertulians i divulgadors televisius (autèntics opinadors, en la terminologia del professor Prats) que han promogut un gran soroll tot avalant una sèrie d'iniciatives de nova planta, sorgides sovint del no-res, més enllà de les modes a I'ús, i que ha deixat somorta una rica tradició i trajectòria pedagògica entre la retòrica, el mercantilisme i la propaganda ideològica. No oblidem que, al capdavall, els mestres també han estat víctimes -ben al contrari del que ha passat amb els banquers- de la crisi que ha suposat un excel.lent brou de cultiu per l'aparició d'un seguit de propostes educatives amb afany de notorietat que no aporten gaire de nou (Nihil novum sub sole) al debat pedagògic, més enllà de l'enrenou i fressa mediàtica.

Sortosament, ens queden intel.lectuals de pedra picada com el professor Xavier Besalú que empren la tribuna prestigiosa d'una institució com I'Institut d'Estudis Catalans per denunciar aquesta deriva tecnològica i mercantilista que no deixa de ser més que una de les múltiples manifestacions de la pedagogia postmoderna, entestada en promoure iniciatives performatives que només busquen l'èxit immediat amb terminologia i llenguatge aparentment innovadors (educació emocional, gamificació, Mindfulness, neurodidàctica, 
excel-lència, resiliència, coaching, orientalisme zen, etc.) però que, si es mira amb atenció, d'una banda ja s'han dit d'una altra manera al llarg de la història de l'educació (d'aquí que alguns hagin retornat al passat de la pedagogia Waldorf o les tècniques montessorianes, sense oblidar les propostes de pedagogs com ara Pestalozzi, Tolstoi, Tagore i Korczak), i, per l'altra, responen pel general als interessos econòmics de les grans corporacions que avalen, a través de les seves fundacions, aquestes estratègies que apunten a un món que ja tenim aquí, postorgànic, transhumanista i posthumanista, és a dir, a un futur d'alta tecnologia que així esdevé el gran repte utòpic -o millor dit, distòpicdel segle XXI a la percaça dels millors executius, per tal que no es perdin els talents que el neoliberalisme necessita -adés i ara- per mantenir la seva hegemonia i colonització del món.

\section{Referències}

Doctor Alexandre Sanvisens Marfull, pedagog i pensador (2005) Barcelona, Publicacions i edicions de la Universitat de Barcelona.

Feixes Sibila, V. (2019) Vida, pensament pedagògic i acció educativa de Pau López Castellote (1929-1994). Lleida, Pagès editors.

Garcia Farrero, J. i Vilanou, C. (2018) «Els inicis de la renovació pedagògica: un compromís educatiu per a una Catalunya progressista». Nous Horitzons, 219, p. 12-17.

Prats, E. (2015) Teorizando en educación: entre erudición, poesía y opinionitis. Barcelona, Editorial UOC. 